\title{
A ficcionalização da história moçambicana nos contos de Lília Momplé
}

\section{Ninguém matou Suhura: estórias que ilustram a história.}

MOMPLÉ, Lília Maria Clara Carrière.

3. ed. Maputo: Edição da Autora, 2007. $104 \mathrm{p}$.

Lília Maria Clara Carrière Momplé nasceu em 19 de março de 1935, na mítica llha de Moçambique, localizada ao norte do país, na província de Nampula. Concluiu seus estudos secundários na capital da colônia, na cidade de Lourenço Marques (hoje Maputo). Na universidade, frequentou durante dois anos o curso de Filologia Germânica, deixando-o para formarse em Serviço Social no Instituto Superior de Serviço Social de Lisboa. Depois de uma temporada na Grã-Bretanha (durante 1964) e de outra no Brasil (de 1968 a 1971), a escritora regressa definitivamente a Moçambique no ano de 1972.

Encerrados os seus estudos em Lisboa, Lília Momplé trabalhou como funcionária da Secretaria de Estado da Cultura como diretora do Fundo para o Desenvolvimento Artístico e Cultural de Moçambique (Fundac) e como secretária-geral da Associação de Escritores de Moçambique (AEMO), durante o período de 1995 a 2001. De 1997 a 2001, acumulou, juntamente com a função de secretária-geral da Aemo, a função de presidente da Instituição. Durante o período em que esteve na Presidência da Associação, não mediu esforços para aumentar a visibilidade das mulheres nas publicações da Instituição. Foi também representante do Conselho Executivo da Unesco, no período compreendido entre 2001 e 2005.

Apesar de suas colaborações dispersas na imprensa, Lília Momplé destaca-se no cenário da literatura moçambicana por seus três livros:
Ninguém matou Suhura (contos, 1988), Neighbours (romance, 1996) e Os olhos da cobra verde (contos, 1997). Em 2001, foi agraciada com o Prêmio Caine para Escritores de África, com o conto "O baile de Celina". Além desse prêmio, recebeu também $\circ 1^{\circ}$ Prêmio de Novelística no Concurso Literário do Centenário da Cidade de Maputo, com o conto "Caniço". Esses dois contos foram originalmente publicados em seu primeiro livro, Ninguém matou Suhura. Lília Momplé tem livros traduzidos para o inglês e o alemão por editoras de reconhecido prestígio, tal como a Heinman.

Ninguém matou Suhura, finalmente, recebe uma merecida reedição, ainda que arcada pela sua própria autora. Esse é um livro de contos composto de maneira singular. As cinco narrativas que o compõem podem ser lidas de maneira independente, mas, ao mesmo tempo, estão interconectadas de maneira temática, através da representação e da denúncia da violenta experiência colonial dos povos de Moçambique e Angola ao longo do século XX. Cada um dos contos retrata um aspecto singular do colonialismo português em África, cobrindo uma linha temporal que se estende de 1935 a 1974. Cada um dos contos inicia com uma data precisa e, à exceção de "Aconteceu em Saua-Saua" (narrativa que abre - livro), cada um deles emerge do universo retratado pela escritora com uma demarcação geográfica precisa, indicando-se a cidade na qual os eventos narrados desenrolam-se. Excetuando-se a última narrativa, intitulada "O último pesadelo", a qual se passa em Luanda, todos os outros contos estão ambientados em Lourenço Marques (a antiga capital colonial, que, após a independência moçambicana, em 1975, passa a chamar-se Maputo e torna-se a capital do país) ou na llha de Moçambique (terra natal da escritora). Em todos os contos, a autora adora um narrador em terceira pessoa e onisciente, e a focalização narrativa oscila entre a focalização interna (na qual a voz narrativa 
tem acesso aos pensamentos e ao universo interior das personagens) e a narrativa externa (na qual, a partir de um locus exterior ao universo diegético instaurado pelos eventos narrados, a voz narrativa emite seus juízos e comentários acerca dos eventos que vão sendo apresentados ao leitor). É mister ressaltar que essa técnica narrativa é uma constante ao longo de todas as obras de Lília Momplé.

Em "Aconteceu em Saua-Saua", relata-se a trágica experiência de Mussa Racua, um humilde camponês recrutado pela administração colonial para cultivar arroz. A administração colonial, arbitrariamente, demarcava as terras a serem cultivadas e distribuía as sementes, estabelecendo também as metas de produtividade agrícola. Caso o camponês em questão não alcançasse a meta, corria o risco de ser recrutado, em nome do pagamento da "dívida", para trabalhar nos campos de sisal. É essa a situação na qual se encontra Mussa Racua, que desesperadamente tenta pedir a seus vizinhos dois sacos de arroz para completar a sua cota de produção:

- Mas tu já viste, irmão, que vida é a nossa? interrompe Mussa Racua - vem essa gente da Administração e marca-te um terreno. Dão-te sementes que não pediste e dizem: tens que tirar daqui três ou seis ou sete sacos, conforme Ihes dá na cabeça. E se por qualquer razão adoecemos ou não cai chuva ou a semente é ruim, e não conseguimos entregar o arroz que eles querem, lá vamos nós parar às plantações. E os donos das plantações ficam contentes porque conseguem uma data de homens para trabalhar de graça. E a gente da Administração fica contente porque recebe dos donos das plantações um tanto por cabeça que entrega. E nós é que vamos rebentando de medo e de trabalho todos os anos. E mal podemos cuidar das nossas machambas que nem dão para comer (p. 12-13).

A preocupação de Mussa Racua em cumprir com a cota estabelecida pela administração colonial não surge em vão. Ele já experienciou na própria pele as agruras do trabalho nas plantações de sisal. Diante do desespero, Mussa Racua divide com o amigo Abudo as amargas recordações do trabalho nos campos:

- Escuta! - continua Mussa Racua, numa exaltação febril - eu nunca te falei daquele sofrimento. Todos os que experimentaram a plantação não querem mais falar daquilo. A comida sabe a merda! E mesmo assim é só o suficiente para um homem agüentar o trabalho.
E aquele sisal que nunca mais acaba. Aquele sisal tem sangue, irmão, está cheio de sangue! A trabalhar sempre doente. Doente e a apanhar porrada. E depois de tanto tempo, vir de lá sem nada... Sem nada, irmão! (p. 13).

Como se já não fosse suficiente a temporada de trabalhos forçados, em condições precárias e sem remuneração nenhuma, depois de sua primeira temporada nos campos de sisal, Mussa Racua, ao regressar para a aldeia de SauaSaua, descobre que sua humilde palhota de camponês foi saqueada e seus poucos pertences roubados, assim como os poucos cabritos que possuía. A esposa também o abandona, pois "não aguentara a longa ausência, sem notícias e sem dinheiro" (p. 17). Tais recordações o deixam aflito, e o inevitável medo de perder a segunda esposa em uma nova temporada de trabalhos forçados na plantação de sisal leva Mussa Racua a uma decisão desesperada: no meio da noite, abandona sua palhota e suicida-se, enforcandose com o auxílio de uma corda em um dos galhos de uma frondosa mangueira à beira da estrada. O administrador colonial da aldeia, após ouvir o relato, contado em língua macua por um senhor transeunte ao Língua (o tradutor local do administrador), expressa sua raiva e impaciência: "- Estes cães assim que lhes cheira a trabalho, arranjam sempre chatices. Ou fogem ou suicidam-se. Maldita raça!" (p. 21).

A grande ironia do conto está no seu encerramento, o qual desvela a violência colonialista e o racismo a ela subjacente, através das palavras do administrador. Após o relato da trajetória de Mussa Racua, a voz narrativa pode isentar-se de manifestar seu posicionamento perante a atitude desesperada do protagonista. Desfralda-se assim, a partir do gesto suicida do protagonista, a denúncia da experiência colonial, e o leitor é conduzido a interpretar a autodestruição do protagonista como a única atitude de resistência possível. As palavras do administrador, por sua vez, não marcam apenas sua indiferença com as populações autóctones de Moçambique. O seu gesto de resistência anticolonialista de Mussa Racua, ao ser lido e interpretado como preguiça e indolência por parte do administrador, vilipendia o cadáver do protagonista, roubando o sentido de seu gesto desesperado: em vez de marcar o espaço simbólico como um germe de resistência, da única resistência possível às arbitrariedades daquele momento histórico, o gesto do protagonista é rasurado e apagado pela episteme colonialista. 
O conto "Caniço" traz à memória do leitor, já em seu título, as reverberações dos "bairros de caniço", aglomerados de pequenas palhotas construídas com caniço e, por vezes, cobertos com folhas de coqueiro, nos quais residiam as populações negras mais humildes, espoliadas pelo jugo colonialista, e que se localizam, em grande quantidade, ainda hoje, nos arredores mais distantes da antiga Lourenço Marques. Cronologicamente situada no ano de 1945, a narrativa inicia nos apresentando a história da família do jovem Naftal, que ainda criança perde o pai em função de uma tuberculose contraída nas profundezas das minas da África do Sul, onde trabalhava. Com a morte do pai, a situação de pobreza da família agrava-se e Aidinha, a irmã mais velha de Naftal, cansada da vida miserável que leva com a família no bairro de caniço, acaba entregandose à prostituição. A mãe, ao descobrir o destino de Aidinha, tenta resgatá-la:

- Vamos para casa, minha filha.

Aidinha não lhe disse que está farta da miséria e que sendo negra, não tinha outro caminho para se livrar dela. Só tornando-se puta. Não disse nada disso, mas respondeu com a fria serenidade de quem há muito tinha feito uma opção:

- Não, mãe, deixe-me viver assim. Para a palhota eu não volto mais. Nunca mais (p. 28).

Para ajudar a família, o jovem Naftal começa a trabalhar como empregado doméstico junto a uma família de brancos, na parte rica da cidade. Tudo corre bem até o dia em que desaparece o relógio de ouro de sua patroa: "Ouve lá, Naftal, não viste meu relógio de ouro?" (p. 34). Naftal entra em pânico, pois sabe que tipo de acusação está subliminarmente presente nessas palavras. Ao fim do dia, quando o patrão chega, ele e o cozinheiro da casa são levados à esquadra policial, e o patrão encarrega a polícia de resolver a questão. Quando o patrão chega em casa, sua esposa já havia resolvido o mistério: sua filha, Mila, havia encontrado o relógio no banheiro e decidido levá-lo à escola para impressionar as colegas. Todavia, mesmo com o mistério resolvido, o patrão se nega a ir até a esquadra para esclarecer o mal-entendido: "A queixa já está lá, não podemos voltar atrás. Deixaos lá apanhar. É pelas vezes que nos roubam e não são descobertos" (p. 35).

A partir de uma cena aparentemente banal, a voz narrativa explicita o clima de desconfiança e bestialização da população negra ante o racismo dos colonos portugueses. Naftal, por sua vez, é retratado ao longo do conto de maneira a enfatizar sua agonística existencial: mesmo sendo um trabalhador honesto e dedicado, o colonialismo racista coloca todos os autóctones sob a suspeita dos "instintos roubadores" dos moçambicanos.

Já em "O baile de Celina", conto que se passa em 1950, retrata-se a dolorosa experiência de Celina, jovem aluna do Liceu Salazar que está prestes a se formar. Embora filha de uma família de poucas posses, Célia tem uma vantagem: sua mãe é modista, o que Ihe permitiu não apenas estudar no Liceu dos brancos, como também Ihe possibilitou ter um vestido vaporoso e elegante para a celebração do fim de seus estudos. Entretanto, chegadas as vésperas do baile, Celina é chamada pelo diretor da instituição e proibida de participar do baile de finalistas por ser negra. Indignada com o fato, retorna a casa, senta-se em sua cama e, com uma tesoura, picota o vestido, em meio às lágrimas oriundas da frustração de não poder participar do baile.

"Ninguém matou Suhura" - conto que dá título ao livro - é, talvez, o que mais explicitamente denuncie as arbitrariedades do colonialismo português em terras moçambicanas. Na primeira parte do conto, relata-se o dia do Senhor Administrador, que mantém uma garçonière em uma região afastada da cidade, para a qual leva as garotas virgens que frequentemente encontra pelas ruas no intuito de violentá-las. $\mathrm{Na}$ segunda parte, conta-se o quotidiano de Suhura, uma jovem humilde que mora com a avó e que termina sua tarde sendo escolhida pelo Senhor Administrador em um dos seus passeios pelas ruas da llha de Moçambique, na província de Nampula, em uma tarde de 1970. Finalmente, na última parte do conto, relata-se o estupro de Suhura, seguido de seu assassinato por parte do Senhor Administrador e da entrega do corpo de Suhura à sua avó, que nada pode fazer senão sepultar, em silêncio, o corpo da neta assassinada.

Finalmente, no último conto do livro, intitulado "O último pesadelo" e ambientado em Luanda, no ano de 1974, são apresentados os recorrentes pesadelos de Eugénio, um colono português que viveu durante algum tempo no Hotel Guaraná, na zona da Gabela, onde se encontrava trabalhando como designer para um rico agrimensor local. As tensões geradas pelos conflitos internos entre os colonos portugueses e os militantes do Movimento Popular pela Libertação de Angola (MPLA) fomentam tal grau de desconfiança por parte dos portugueses residentes em Gabela que, em dada noite, os hóspedes do Hotel Guaraná 
reúnem todos os funcionários negros do estabelecimento e assassinam-nos a pauladas, chutes e pontapés. Eugénio, que nunca escondeu sua simpatia pelo MPLA, é tomado pelos outros hóspedes do Hotel e obrigado a assistir à carnificina, sendo, em seguida, expulso da Gabela com toda a sua família, tendo de se refugiar em Luanda.

No projeto ficcional de Lília Momplé, tornase evidente um esforço de vencer a amnésia social, com vistas a manter vivas as recordações das violências e das arbitrariedades colonialistas. A beleza de seus contos é diametralmente proporcional à crueza da violência descrita ao longo das páginas de Ninguém matou Suhura. É recorrente, em suas narrativas, a presença de uma melancolia histórica, provocada pelo apagamento das agruras da luta pela independência das ex-colônias africanas, e de um atento olhar para os desfavorecidos que mais sofreram durante a história moçambicana ao longo do século XX. Por trás de personagens como Mussa Racua, Naftal, Aidinha, Celina, Suhura, Eugénio e suas trágicas trajetórias, é possível para o leitor de hoje vislumbrar um pouco da experiência colonial moçambicana através da perspectiva dos sujeitos silenciados ao longo da história recente.

\section{Referências}

ALÓs, Anselmo Peres. "Histórias lusófonas das margens do índico: As mãos dos pretos (antologia do conto moçambicano)". Revista
África e Africanidades, ano 2, n. 7, p. 1-6, nov. 2009. Afro-brasileiros: construindo e reconstruindo os rumos da história. Disponível em: <http://africaeafricanidades.com.br/ documentos/As_maos_de_pretos.pdf $>$. Acesso em: 10 jun. 2010.

ANGIUS, Fernanda. "A actual literatura em Moçambique: a propósito de uma literatura em construção". Latittudes, n. 7, p. 19-22, dic. 99/enero 2000.

MOMPLÉ, Lília. Ninguém matou Suhura. Maputo: Associação dos Escritores Moçambicanos, 1988. 82 p. (Coleção Karingana, n. 7).

. Neighbours. Maputo: Associação dos Escritores Moçambicanos, 1995. 109 p. (Coleção Karingana, n. 16).

. Os olhos da cobra verde. Maputo: Associação dos Escritores Moçambicanos, 1997. 89 p. (Coleção Karingana, n. 18).

. Ninguém matou Suhura. 3. ed. Maputo: Edição da Autora, 2007. 104 p.

"Stress". In: SAÚTE, Nelson (Org.). As mãos dos pretos: antologia do conto moçambicano. Lisboa: Dom Quixote, 2000. p. 123142.

ROTHWELL, Phillip. "Momplé's Melancholia: Mourning for Mozambique." Portuguese Studies Review, v. 10, n. 1, p. 185-193, 2002.

\section{Anselmo Peres Alós}

Universidade Federal da Integração Latino-Americana 